\title{
Cytotoxic and bioactive properties of different color tulip flowers and degradation kinetic of tulip flower anthocyanins
}

\author{
Osman Sagdic ${ }^{\mathrm{a}, *}$, Lutfiye Ekici ${ }^{\mathrm{b}}$, Ismet Ozturk ${ }^{\mathrm{b}}$, Turgay Tekinay ${ }^{\mathrm{c}, \mathrm{d}}$, Busra Polat ${ }^{\mathrm{b}}$, Bilge Tastemur $^{\mathrm{b}}$, \\ Okan Bayram ${ }^{\text {b }}$, Berna Senturk ${ }^{\mathrm{e}}$ \\ ${ }^{a}$ Yildiz Technical University, Faculty of Chemical and Metallurgical Engineering, Department of Food Engineering, 34210 Istanbul, Turkey \\ ${ }^{\mathrm{b}}$ Erciyes University, Faculty of Engineering, Department of Food Engineering, 38039 Kayseri, Turkey \\ ${ }^{\mathrm{C}}$ Gazi University, Life Sciences Application and Research Center, TR-06830 Ankara, Turkey \\ ${ }^{\mathrm{d}}$ Gazi University, Polath Science and Literature Faculty, TR-06900 Ankara, Turkey \\ e Bilkent University, Laboratory of Sustainable Technologies, UNAM Institute of Materials Science and Nanotechnology, 06800 Ankara, Turkey
}

\section{A R T I C L E I N F O}

\section{Article history:}

Received 2 April 2013

Accepted 15 May 2013

Available online 25 May 2013

\section{Keywords:}

Wasted tulip flowers

Bioactivity

Cytotoxicity

Kinetic

\begin{abstract}
A B S T R A C T
This study was conducted to determine the potential use of anthocyanin-based extracts (ABEs) of wasted tulip flowers as food/drug colorants. For this aim, wasted tulip flowers were samples and analyzed for their bioactive properties and cytotoxicity. Total phenolic contents of the extracts of the claret red ( $126.55 \mathrm{mg}$ of gallic acid equivalent (GAE)/g dry extract) and orange-red (113.76 mg GAE/g dry extract) flowers were the higher than those of the other tulip flowers. Total anthocyanin levels of the violet, orange-red, claret red and pink tulip flower extracts were determined as 265.04, 236.49, 839.08 and $404.45 \mathrm{mg}$ pelargonidin 3-glucoside/kg dry extract, respectively and these levels were higher than those of the other flowers. The extracts were more effective for the inhibition of Listeria monocytogenes, Staphylococcus aureus and Yersinia enterocolitica compared to other tested bacteria. Additionally, the cytotoxic effects of five different tulip flower extracts on human breast adenocarcinoma (MCF-7) cell line were investigated. The results showed that the orange red, pink and violet extracts had no cytotoxic activity against MCF-7 cell lines while yellow and claret red extracts appeared to be toxic for the cells. Overall, the extracts of tulip flowers with different colors possess remarkable bioactive and cytotoxic properties. (c) 2013 Elsevier Ltd. All rights reserved.
\end{abstract}

\section{Introduction}

Color is one of the most important food quality characteristics and food manufacturers have been used both natural and synthetic colorants for centuries (Kammerer et al., 2007; Bechtold and Mussak, 2009). However, negative effects of synthetic colorants on health have been well demonstrated, therefore consumers are demanding healthy foods which do not contain those additives. For this reason, natural colorants, especially anthocyanins, have been used extensively in food industry and have drawn the attention of researchers (Silbergeld and Anderson, 1982; Kammerer et al., 2007). Anthocyanins comprise the largest group of water soluble pigments which are responsible for a wide range of colors (Bridle and Timberlake, 1997; Cevallos-Casals and Cisneros-Zevallos, 2004). The color and stability of anthocyanins in food systems can vary depending on several factors such as structure and concentration of the pigment, $\mathrm{pH}$, temperature, light intensity and quality, presence of copigments, metallicions, enzymes, oxygen, ascorbic acid, sugars and their degradation products and sulfur

\footnotetext{
* Corresponding author. Tel.: +90 21238345 74; fax: +90 2123834011 .

E-mail addresses: osagdic@yildiz.edu.tr, sagdic@gmail.com (O. Sagdic).
}

dioxide (Cevallos-Casals and Cisneros-Zevallos, 2004). In addition to their coloring properties, anthocyanins are also attractive for their antioxidant activity which makes them as disease-prevention compounds (Kammerer et al., 2007).

Edible flowers have been used traditionally for their unique taste and colors and they have been more popular by the increase in the number of publications such as edible-flower cookbooks, magazine articles and television programs about them. Edible flowers are used in salads, soups, entrees, desserts, and drinks (Kelley et al., 2003; Mlcek and Rop, 2011). Researchers have been claimed that edible flowers are important sources of antioxidant compounds (Mlcek and Rop, 2011; Tai et al., 2011).

The genus Tulipa L. is a member of family Liliaceae and represented by 16 taxa (15 species), and two of them are endemic in Turkey (Mlcek and Rop, 2011). Food manufacturers are seeking natural coloring alternatives to synthetic ones due to their possible harmful effects on health and negative public perception. It has been shown that some synthetic colorants provoke hypersensitivity reactions such as urticaria, angioneurotic edema, and asthma (Michaelsson and Juhlin, 1973; Granholt and Thune, 1975; Vidotti et al., 2006). 
Many artificial food colorants also contain toxic chemicals which are responsible for many diseases and behavioral problems such as hyperkinesis and learning disabilities (H-LD) (Feingold, 1975; Ganesan et al., 2011). To overcome these effects, there is an ongoing effort, and plant extracts have been suggested to be used as coloring agents; however, very few of them are approved for use in food industry. Although natural food colorants are more desirable than artificial ones, only limited information has been available in the literature about the toxic effects of natural food dyes on mammals. Therefore, it is important to study the toxicity of the flower extracts that will be used as food coloring, such as tulip flowers based anthocyanin extracts. The aims of the present study were: (i) to determine total phenolic, total anthocyanin, antiradical, antioxidant, antimicrobial and toxicity properties of the tulip flower samples and (ii) to determine thermal degradation kinetics of tulip flower anthocyanin based extracts at 70,80 and $90^{\circ} \mathrm{C}$.

\section{Materials and methods}

\subsection{Plant material}

Tulip (Tulipa gesneriana L.) flower samples were obtained from Istanbul Metropolitan Municipality, Tree and Landscape Co. (Istanbul, Turkey). All of the tulip samples can commercially be found reference varieties. Colors of tulip flowers were pink ( $T$. gesneriana 'Leo Visser'), orange-red ( $T$. gesneriana 'Red Ring Hood'), claret red (T. gesneriana 'Ben Van Zanten'), violet (T. gesneriana 'Negrita') and yellow ( $T$. gesneriana 'Yokohama'). After tulips' sprouts and stem parts were removed, flowe petals of the tulips were dried at the room temperature. Dried tulip flower's petals were stored at room temperature in the dark conditions until use.

\subsection{Extraction method}

Ethanol $(\geqslant 99.8 \%$ ): distilled water $(1: 1 \mathrm{v} / \mathrm{v})$ mixture acidified with $0.01 \% \mathrm{HCl}$ solvent was used for the extraction of anthocyanin pigments from the tulip flowers. Raw materials were allocated to small pieces by a laboratory type grinder. Sample: solvent ratio was adjusted to be $1: 19.200 \mathrm{~mL}$ solvent was added in $50 \mathrm{~g}$ of sample and homogenized with ultra-turrax ( $1 \mathrm{~min}$ in high speed grinder). After the homogenization, $275 \mathrm{~mL}$ of remaining solvent was added to sample and extracted in shaking water-bath (Memmert WB-22, Germany) at $35^{\circ} \mathrm{C}$ for $1 \mathrm{~h}$. Following the first extraction, the extract was filtered with filter paper and then $475 \mathrm{~mL}$ of solvent was added. Second extraction was carried out under the former conditions. Solvents were collected and filtered using Whatman no: 1 filter paper under vacuum conditions. After that, the residual solvent was evaporated from the extract at $50{ }^{\circ} \mathrm{C}$ using a rotary evaporator.

\subsection{Determination of total phenolic content}

The Folin-Ciocalteu method was used with some modifications to determine total phenolic content of the tulip flower extracts (Singleton and Rossi, 1965). The extracts were diluted in certain concentrations with ethanol: distilled water (1:1). $2400 \mu \mathrm{L}$ of distilled water, $40 \mu \mathrm{L}$ of the extract and $200 \mu \mathrm{L}$ of Folin-Ciocalteu reagent (Merck, Darmstadt, Germany) were added in each tube, respectively. Then $600 \mu \mathrm{L}$ saturated $\mathrm{Na}_{2} \mathrm{CO}_{3}(20 \%)$ and finally $760 \mu \mathrm{L}$ of distilled water were added. After $2 \mathrm{~h}$ incubation in a dark environment, the absorbances of analytes were measured at $765 \mathrm{~nm}$ with a spectrophotometer (Varian Cary 100 Conc. UV-Visible, USA). A standard curve with serial gallic acid solution $(0-1 \mathrm{mg} / \mathrm{mL})$ was use for calibration. The results were expressed as $\mathrm{mg}$ gallic acid equivalent (mg GAE) per $g$ of dry extract.

\subsection{Determination of total anthocyanin content}

Total anthocyanin contents of the extracts were determined using the pH-differential method (Fuleki and Francis, 1968). The results were calculated based on pelargonidin-3-glucoside with a molecular weight of 433.2 and molar absorbance of 22400 . Total anthocyanin contents were calculated according to the following formula (Wrolstad, 1976):

Anthocyanin $\mathrm{mg} / \mathrm{L}=(\Delta A / \varepsilon \times L) 10^{3}(\mathrm{MW})(\mathrm{DF})$

$\Delta A$ is the difference of absorbance; $\varepsilon$ the molar absorbance; $L$ the thickness of cuvette, $\mathrm{cm}$; MW the molecular weight; and DF is the dilution factor.

\subsection{Determination of free radical scavenging activity}

The scavenging activity of the extracts for the radical 1,1-diphenyl-2-picrylhydrazyl (DPPH) was measured as described by Brand-Williams et al. (1995) with some modifications. A series of extract concentration were prepared, and $200 \mu \mathrm{L}$ of the samples was mixed with $4000 \mu \mathrm{L}$ of $0.1 \mathrm{mM}$ DPPH (Sigma St. Louis, MO, USA) in methanol. After the incubation for $30 \mathrm{~min}$ in ambient and dark conditions, the absorbance of sample was measured at $517 \mathrm{~nm}$ using a spectrophotometer. Solvent system was used instead of sample in the control. Methanol was used as blank to zero the absorbance. Antiradical activity (\%) of the samples was calculated by the following equation:

$\%$ Inhibition $=100 \times(($ absorbance of control

\section{- absorbance of sample)/absorbance of control)}

The amounts of the extract required for $50 \%$ inhibition of DPPH were determined graphically by means of \% Inhibition.

\subsection{Determination of total antioxidant capacity}

The antioxidant activity of the anthocyanin-based extracts (ABEs) was determined by phosphomolybdenum reduction method described by Prieto et al. (1999). In this assay, $400 \mu \mathrm{L}$ solution of the extracts was added and mixed with $4 \mathrm{~mL}$ of the reagent solution ( $0.6 \mathrm{M}$ sulfuric acid, $28 \mathrm{mM}$ sodium phosphate and $4 \mathrm{mM}$ ammonium molybdate). After homogenization with vortex, reaction mixture was incubated in a shaking water-bath (Memmert WB-22, Germany) at $95^{\circ} \mathrm{C}$ for $90 \mathrm{~min}$. Then the samples were cooled rapidly at room temperature and the absorbances of the analytes were measured at $695 \mathrm{~nm}$. The antioxidant capacity of the extracts was expressed as the ascorbic acid equivalents in milligrams/g dry extract.

\subsection{Determination of antimicrobial activity}

The agar well diffusion method was used to test antimicrobial activity of the extracts. Fifteen microorganisms including 13 bacteria and 2 yeast strain were used as test organisms: Aeromonas hydrophila ATCC 7965, Bacillus cereus ATCC 33019, Bacillus subtilis ATCC 6633, Enterobacter cloacae ATCC 13047, Escherichia coli ATCC 11230, E. coli 0157:H7 ATCC 33150, Klebsiella pneumoniae ATCC 13883, Listeria monocytogenes ATCC 7644, Proteus vulgaris ATCC 13319, Pseudomonas aeruginosa ATCC 17853, Salmonella typhimurium ATCC 14028, Staphylococcus aureus ATCC 25923, Yersinia enterocolitica ATCC 1501, Saccharomyces cerevisiae BC 5461 and Candida albicans ATCC 1223 . Bacteria were inoculated in nutrient broth and incubated at $35^{\circ} \mathrm{C}$ for $24 \mathrm{~h}$ while the yeasts were activated in malt extract broth at $27{ }^{\circ} \mathrm{C}$ for $24 \mathrm{~h}$. Then $1 \%$ of microorganisms was added in nutrient broth and malt extract broth and reincubated for $18 \mathrm{~h}$. Final cell concentrations were measured as $10^{6}-10^{7}$ colony forming unit (CFU)/mL. Microbial cultures (1\%) were added to nutrient agar and malt extract agar at $43-45^{\circ} \mathrm{C}$ and poured $25 \mathrm{~mL}$ of agar into petri dishes. Agars were allowed to be solidified at $4{ }^{\circ} \mathrm{C}$ for $1 \mathrm{~h}$. Then four equidistant holes were bored by sterile cork borers $(\emptyset=4 \mathrm{~mm}) .50 \mu \mathrm{L}$ of $1 \%, 2.5 \%, 5 \%$ or $10 \%$ extract solutions in absolute ethanol was added to the holes using a micropipette. Absolute ethanol without the extract was used as a control. Yeasts and bacteria were incubated at $27^{\circ} \mathrm{C}$ and $35^{\circ} \mathrm{C}$ for $18-24 \mathrm{~h}$, respectively. Following the incubation, formed inhibition zones around the holes were measured and expressed as millimeter $(\mathrm{mm})$ (Sagdic et al., 2003).

\subsection{Determination of thermal stability of anthocyanins}

The thermal stabilities of tulip flower ABEs were studied at $\mathrm{pH} 3.5$ in sodium citrate buffer solutions at 70 and $80^{\circ} \mathrm{C}$ for $420 \mathrm{~min}$ and at $90^{\circ} \mathrm{C}$ for $180 \mathrm{~min}$. The $\mathrm{pH}$ value of the buffer systems was controlled using a calibrated $\mathrm{pH}$ meter (WTW, Werkstatten, Germany). For coloring, ABEs containing $4 \mathrm{mg}$ anthocyanin were added into the $100 \mathrm{~mL}$ of the buffer, divided into $15 \mathrm{~mL}$ portions. Each portion was poured into Pyrex tubes and incubated in a thermostatic water bath (Memmert WB-22, Germany) at following temperature. The samples were removed from the water bath at $30 \mathrm{~min}$ intervals and rapidly cooled under running tap water. The anthocyanin contents of the samples were determined according to pH-differential method (Giusti and Wrolstad, 2001).

\subsection{Kinetics of anthocyanin degradation during heating}

Thermal degradation of the ABEs in the buffer followed first order reaction kinetics. Previous studies have shown that thermal degradation of anthocyanins follows a first-order reaction (Cemeroglu et al., 1994; Dyrby et al., 2001; Wang and Xu, 2007). Kinetic coefficients were calculated by the following equations (Kirca, 2004):

$-(\mathrm{d} C / \mathrm{d} t)=k C$

$\ln \left(C / C_{0}\right)=-k t$

$C_{0}$ is the initial anthocyanin content; $C$ the anthocyanin content after $t$ hour of heating; $k$ the reaction rate constant; and $t$ is the time (hour). 
2.9.1. Calculation of reaction rate constant

Applied to the each temperature anthocyanin losses, " $y$ " axis, the times " $x$ " axis, placed in a semi-logarithmic scale graph a linear curve was obtained. The equation of the curve was calculated by applying of linear regression analysis in this curve. The reaction rate constant was calculated using the slope of the curve (Kirca, 2004).

$k=($ slope $) \times 2.303$

\subsubsection{Calculation of activation energy}

The Arrhenius model was used to describe the temperature dependency of anthocyanin degradation (Kirca, 2004; Wang and Xu, 2007).

$k=k_{0} \times \exp ^{-E a / R T}$

Calculations were obtained by taking the logarithm of the above equation and used in the form shown in the following equation:

$\ln k=\left[\left(-E_{a} / R\right) \times(1 / T)\right]+\ln k_{0}$

$k$ is the reaction rate constant; $k_{0}$ the frequency factor; $E_{a}$ the activation energy (J/ $\mathrm{mol}) ; R$ the universal gas constant $(8.314 \mathrm{~J} / \mathrm{mol} / \mathrm{K})$; and $T$ is the temperature (Kelvin, $\mathrm{K})$.

\subsubsection{Calculation of half-life periods $\left(t_{1 / 2}\right)$}

Half-lives $\left(t_{1 / 2}\right)$, the time needed for $50 \%$ degradation of anthocyanins, were calculated according to the formula which was given below for first order reaction kinetics (Kirca, 2004).

$t_{1 / 2}=-\ln (0.5) \times k^{-1}$

\subsection{Cell culture}

Human breast adenocarcinoma (MCF-7) cells were grown to confluence at $37{ }^{\circ} \mathrm{C}$ under $5 \% \mathrm{CO}_{2}$ in Dulbecco's Modified Eagle Serum (DMEM) containing $1 \%$ penicillin/ streptomycin, 10\% fetal bovine serum (FBS) and $2 \mathrm{mM}$ L-glutamine.

\subsection{Cytotoxicity assay in vitro}

Cells in the logarithmic growth phase were washed once with phosphate-buffered saline, trypsinized and resuspended in fresh medium. The cells were seeded in 96 -well plates at $5 \times 10^{3}$ cells/well. After $24 \mathrm{~h}$ of culture, the medium was removed by aspiration and replaced with $100 \mu \mathrm{L}$ of fresh medium containing tulip flower extract. The treatments were performed with $500 \mu \mathrm{g} / \mathrm{mL}$ tulip flower extract for 24,48 and $72 \mathrm{~h}$. After addition of the extracts, cytotoxicity was assayed by the 3-(4,5-dimethyl-2-thiazolyl)-2,5-diphenyltetrazolium bromide (MTT) reduction assay (Sigma, Aldrich). At least two well columns containing cells without the extract were used as a negative control. MTT solution $(10 \mu \mathrm{L})$ was added to each well, and the plates were incubated in the dark for $4 \mathrm{~h}$ at $37^{\circ} \mathrm{C}$. At the end of the incubation period, the medium was removed and the purple formazan product was dissolved in $50 \mathrm{~mL}$ of dimethylsulfoxide. The optical density was measured at $570 \mathrm{~nm}$ with $680 \mathrm{~nm}$ using a microplate reader (SpectraMax, M5). The optical densities (ODs) of wells containing cells and MTT without the extract were considered as OD control. All the experiments were performed in triplicate (Liu et al., 2005).

\subsection{Statistical analysis}

All data represent means \pm S.E.M. Statistical analysis was performed using analysis of variance followed by the Student's $t$-test.

\section{Results}

\subsection{Total phenolic contents of the flower extracts}

Yields of the ABEs obtained from five different tulip flowers were given in Table 1 while Table 2 shows total phenolic (mg $\mathrm{GAE} / \mathrm{g}$ dry extract), total anthocyanin level (mg pelargonidin 3-glycoside/kg dry extract), antioxidant activity (mg AAE/g dry extract) and antiradical capacity $\left(\mathrm{IC}_{50}: \mu \mathrm{g} / \mathrm{mL}\right)$ of the extracts. Total phenolic content measured by Folin-Ciocalteu method for tulips ranged from $2.55 \pm 0.55$ to $126.55 \pm 0.79$ (mg GAE/g dry extract). The claret red sample had the highest value of the total phenolic content which is $126.55 \pm 0.79$ (mg GAE/g dry extract) and yellow one has the lowest value which is $2.55 \pm 0.55$ (mg GAE/g dry extract) (Table 2).
Table 1

Yields of ABEs obtained from the tulip flowers at different colors.

\begin{tabular}{ll}
\hline Flower petal color & Yield (\%) \\
\hline Claret red & 44.64 \\
Orange-red & 58.65 \\
Pink & 44.70 \\
Violet & 50.31 \\
Yellow & 43.17 \\
\hline
\end{tabular}

\subsection{Total anthocyanin contents of ABEs}

Total anthocyanin amounts ranged between $839.08 \pm 4.22$ and $236.49 \pm 3.68 \mathrm{mg}$ pelargonidin 3 -glicoside/ $\mathrm{kg}$ dry extract for claret red and orange-red samples, respectively. Anthocyanin amount of the yellow sample was not detected as expected (Table 2).

\subsection{Antioxidant activity and antiradical capacity of ABES}

On the contrary of total phenolic and total anthocyanin amount, orange-red sample had the highest antioxidant activity and antiradical capacity $\left(\mathrm{IC}_{50}\right)$ values which are $48.69 \pm 1.01 \mathrm{mg}$ AAE $/ \mathrm{g}$ dry extract and $159.82 \pm 2.76 \mu \mathrm{g} / \mathrm{mL}$, respectively (Table 2).

\subsection{Antimicrobial activities of ABEs}

Antimicrobial activities of ABEs were determined using agar well diffusion method. The antimicrobial activity of the extracts was tested against 15 microorganisms including 13 bacteria and two yeast strains. Antimicrobial activity of ABEs prepared at different concentrations (1\%, $2 \%, 5 \%$ and $10 \%$ ) was indicated in Table 3. The extracts were more efficient against L. monocytogenes, S. aureus and $Y$. enterocolitica than the other tested bacteria. In general, effects of the extracts on the microorganisms increased at higher concentrations. However, the extracts had no antimicrobial effect against two yeasts tested.

\subsection{The heating stabilities of ABEs of tulip flowers}

Kinetic parameters for the degradation of tulip anthocyanins in citrate buffers at pH 3.5 during heating can be seen in Table 4 . While claret red tulip anthocyanins showed higher temperature stability, violet tulip anthocyanins exhibited the lowest stability. As it can be seen in Table 4, increasing temperature caused decreases in $t_{1 / 2}$ values. It was determined that degradation kinetics of the ABEs obtained from different colors of tulips followed a first-order reaction at $\mathrm{pH} 3.5$, the typical $\mathrm{pH}$ of fruit juices (Fig. 1). These results are in agreement with previous literatures (Kirca et al., 2003, 2007). The heating stability of yellow tulip flowers was not tested since they do not possess anthocyanin. Activation energy values of the tulips were calculated to be $68.69 \pm 1.56 \mathrm{~kJ} / \mathrm{mol}$ for claret red, $76.00 \pm 8.29 \mathrm{~kJ} / \mathrm{mol}$ for orangered, $70.14 \pm 0.00 \mathrm{~kJ} / \mathrm{mol}$ for both of pink and violet. Statistical analyses revealed that the color of tulip had no significant effect on $E_{a}$ values of the tulips $(P>0.05)$.

\subsection{Toxicity properties of the tulip flower extracts}

We studied the cytotoxic effects of tulip flower extracts with five different colors on MCF-7 cell lines using the MTT assay for cell toxicity (Fig. 2). MTT assay was performed in vitro similar to Liu et al. (2005). The cytotoxicity of the plant extracts was determined by comparison of growth of non-treated cells with 
Table 2

Bioactive properties of the ABEs obtained from different color tulip flowers.

\begin{tabular}{|c|c|c|c|c|c|}
\hline & \multicolumn{5}{|c|}{ Flower petal color } \\
\hline & Claret red & Orange-red & Pink & Violet & Yellow \\
\hline TPC & $126.55 \pm 0.79$ & $113.76 \pm 0.27$ & $73.74 \pm 1.10$ & $80.52 \pm 0.80$ & $2.55 \pm 0.55$ \\
\hline TA & $839.08 \pm 4.22$ & $236.49 \pm 3.68$ & $404.45 \pm 1.99$ & $265.04 \pm 3.91$ & - \\
\hline $\mathrm{AA}$ & $31.36 \pm 0.91$ & $48.69 \pm 1.01$ & $26.15 \pm 5.09$ & $28.26 \pm 0.27$ & $23.94 \pm 0.71$ \\
\hline $\mathrm{IC}_{50}$ & $62.46 \pm 3.04$ & $159.82 \pm 2.76$ & $122.81 \pm 5.54$ & $122.79 \pm 1.77$ & $126.45 \pm 4.91$ \\
\hline
\end{tabular}

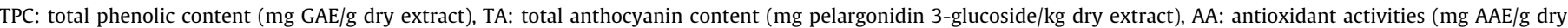
extract), $\mathrm{IC}_{50}$ : antiradical capacity $(\mu \mathrm{g} / \mathrm{mL}),-$ : not detected.

treated ones. Three measurements were performed at time point $24 \mathrm{~h}, 48 \mathrm{~h}$ and $72 \mathrm{~h}$ in vitro, after cells were treated with tulip flower extracts. Results showed that plants extracts did not cause any cell death up to 3 days. Orange-red, pink and violet plants did not show any cytotoxicity in MCF-7 cells compared to control. However, yellow and claret red tulip flower extracts decreased cell viability; survival rate of cells reduced up to $90 \%$ after $72 \mathrm{~h}$ treatments. Additionally, cytotoxicity experiment was performed in the absence of cells in order to show MTT reduction was due to cell respiration and independent of anthocyanin-based extracts (data were not shown).

\section{Discussion}

Phenolic and anthocyanin contents of the tulips with different colors varied in a wide range and were significantly $(P<0.05)$ different from each other. The highest total phenolic and anthocyanin contents and antiradical capacity were observed in claret red petals. These results are in accordance with the literature. Friedman et al. (2010) found that red petal (San Francisco cultivar) roses had the highest anthocyanin and hydrophilic antioxidant levels among different garden rose cultivars selected as edible flowers while phenolic content of yellow tulip petals were lower than other samples. Kaisoon et al. (2012) reported that Tagetes erecta (yellow) flowers contained higher level of phenolic compounds (1107.5 mg/100 g dry weight) than Cosmos sulphureus (yellow-orange), Antigonon leptopus (pink) and Bougainvillea glabra (pinkpurple) which are used as flavoring in salads and flower teas in Thailand. Anthocyanin and phenolic contents of the petals of orange Nasturtium flowers were $72 \mathrm{mg} / 100 \mathrm{~g}$ FW (Fresh weight) and $406 \mathrm{mg} \mathrm{GAE} / 100 \mathrm{~g}$ FW, respectively (Garzón and Wrolstad, 2009) which were incomparable with our results. Total phenolic contents of the extracts of Chaerophyllum macropodum, Sophora viciifolia and Michelia champaca were $30.2 \pm 0.4 \mathrm{mg} \mathrm{GAE} / \mathrm{g}$, $75.2 \pm 4.2 \mathrm{mg} \mathrm{GAE} / \mathrm{g}$ and $7.75 \pm 0.7 \mathrm{mg} \mathrm{GAE} / \mathrm{g}$, respectively (Ebrahimabadi et al., 2010; Nagavani and Rao, 2010; Tai et al., 2011). Those values were lower than our data obtained from claret red, orange-red and violet tulip flowers.

In our study, the lowest antiradical capacity $\left(\mathrm{IC}_{50}\right)$ was detected in orange-red $(159.82 \pm 2.76 \mu \mathrm{g} / \mathrm{mL})$ tulip petals while the highest was determined in claret red petals $(62.46 \pm 3.04 \mu \mathrm{g} / \mathrm{mL})$. Antiradical capacities of $C$. macropodum and S. viciifolia were $167.1 \mu \mathrm{g} / \mathrm{mL}$ and $20.7 \mu \mathrm{g} / \mathrm{mL}$ (Ebrahimabadi et al., 2010; Tai et al., 2011). Antioxidant activities of the tulip flowers ranged from 23.94 AAE/g dry extract to $48.69 \pm 1.01 \mathrm{mg}$ AAE/g dry extract (Table 2). Laloo and Sah (2011) reported that antioxidant activities of Cinnamomum wightii, Ochrocarpus longifolius and Mesua ferrea were $205 \pm 1.44$, $108.33 \pm 1.59$ and $91.67 \pm 2.16 \mathrm{mg} \mathrm{AAE} / \mathrm{g}$ plant extract, respectively which were all higher than our results.

Ksouri et al. (2009) determined antibacterial and antifungal activity of extracts of Tamarix gallica leaves and flowers against the bacteria Staphylococcus epidermidis, S. aureus, Micrococcus luteus, E. coli and P. aeruginosa and against the fungi Candida kefyr,
C. holmii, C. albicans, C. sake and C. glabrata. Flower extracts were more active against bacteria than the leaf extracts. The most sensitive and resistant bacteria against the extracts were M. luteus and E. coli, respectively. Organ extracts showed a weakly to moderate activity against the tested Candida species. In another study (Koncic et al., 2010), aqueous extracts of Moltkia petraea did not show antimicrobial activity against tested fungi (C. albicans and Aspergillus niger), Gram-positive (B. subtilis and S. aureus) and Gram-negative bacteria ( $E$. coli and $P$. aeruginosa). According to Samec et al. (2010), $66.66 \mathrm{mg} / \mathrm{mL}$ of the water extracts of Teucrium ardiuni flowers had no antimicrobial activity. Infusions of $T$. aurdini flowers and leaves were also ineffective against $E$. coli, P. aeruginosa, C. albicans and $A$. niger.

Thermal kinetics of anthocyanins of several plants such as blackberry juice and black carrot have been investigated by some researchers (Kammerer et al., 2004; Wang and Xu, 2007; Harbourne et al., 2008). However, to the best of our knowledge, there has been no report about the heat stability of tulip flower anthocyanins. In the present study, heating stabilities of tulip flower anthocyanins were ordered as claret red $>$ pink $\geqslant$ orange-red $>$ violet. Wang and $\mathrm{Xu}$ (2007) determined $k$ values of blackberry juice anthocyanins as $1.32 \times 10^{-3}, 2.47 \times 10^{-3}$ and $3.94 \times 10^{-3} \mathrm{~min}^{-1}$ for 70,80 and $90^{\circ} \mathrm{C}$, respectively. These results indicate that stability of blackberry anthocyanins was relatively higher than that of tulip anthocyanins. In another research, $k$ values of red cabbage, blackcurrant, elderberry and black grape anthocyanins in $\mathrm{pH} 3.0$ model systems at $80^{\circ} \mathrm{C}$ were found to be $0.06 \times 10^{-3}$, $1.45 \times 10^{-3}, 3.0 \times 10^{-3}$ and $5.33 \times 10^{-3} \mathrm{~min}^{-1}$, respectively (Dyrby et al., 2001). In the present study, lower $k$ values indicate that the anthocyanins in all tulip flower samples (claret red, orange red, pink and violet) presented in Table 4 were more stable than black grape anthocyanins. It is well known that as the temperature increases, $k$ value also increases while a decrease occurs in $t_{1 / 2}$ value (Kirca et al., 2003, 2007; Wang and Xu, 2007; Harbourne et al., $2008)$. In this study, it can be understood from $t_{1 / 2}$ values that claret red tulip anthocyanins were more stable than the other tulip anthocyanins.

The dependency of the degradation of tulip anthocyanins on temperature is seen in Table 4. Activation energy $\left(E_{a}\right)$ values of the anthocyanins ranging from 68.69 to $76.00 \mathrm{~kJ} / \mathrm{mol}$ were consistent with those of elderberry (Sambucus nigra), strawberry (Fragaria $x$ ananassa) and black carrot (Daucus carota ssp. sativus var. atrorubens) anthocyanins varying from 62.76 to $79.50 \mathrm{~kJ} / \mathrm{mol}$ (Reyes and Cisneros-Zevallos, 2007). As expected, higher temperature and longer heating periods increased the degradation of anthocyanins in the tulip flowers. Anthocyanin composition, extraction conditions, storage temperature and heating temperature are among the important factors influencing the degradation of anthocyanins (Kirca et al., 2003, 2007; Wang and Xu, 2007; Harbourne et al., 2008; Pliszka et al., 2009).

Cytotoxicity test is a critical evaluation for approving natural colors as food colorings. Choice of the method to test the viability and proliferation of the cells is also crucial for quantitative assessment of cytotoxic activities of the plant extracts. MTT is a 
Table 3

Antimicrobial activities of ABEs obtained from different color tulip flowers (inhibition zone diameter, $\mathrm{mm}$ ).

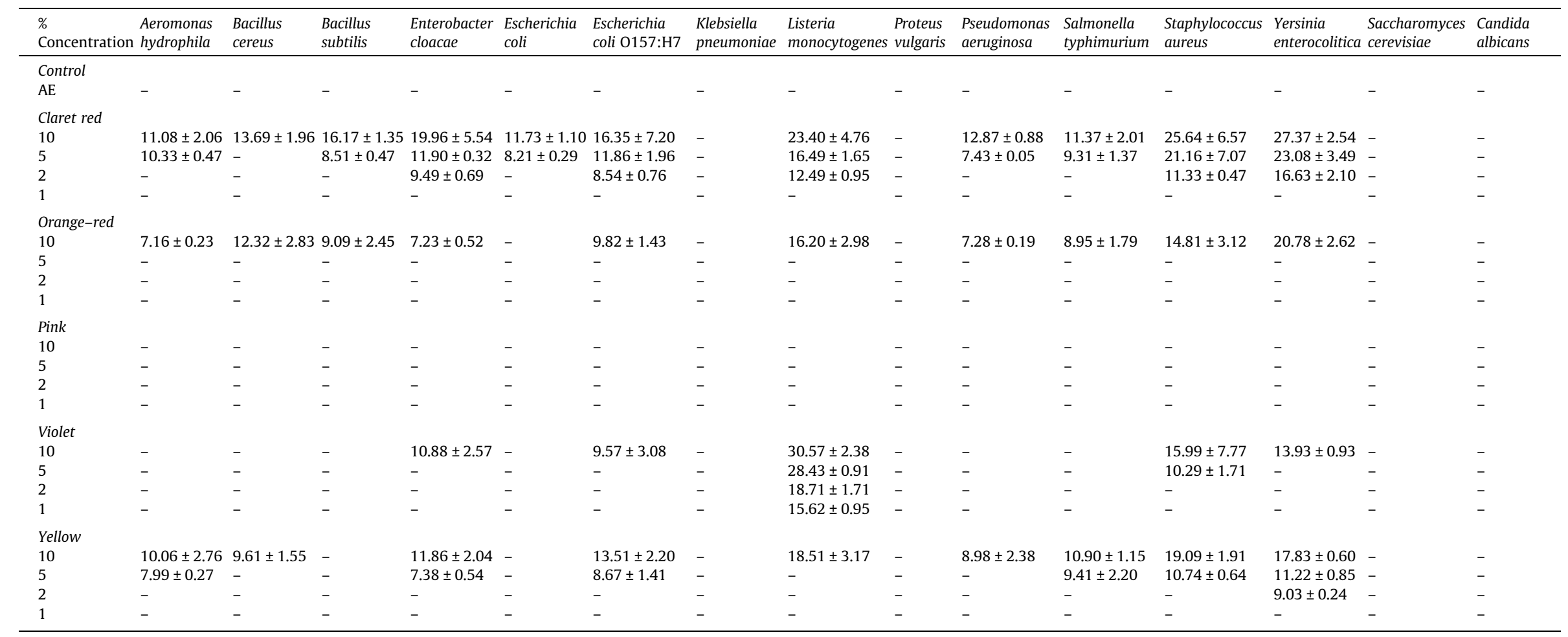

AE: Absolute ethanol.

-: not effective. 
Table 4

Reaction rate constant $(k)$ and half-life $\left(t_{1 / 2}\right)$ values of ABEs obtained from different color tulip flowers at $\mathrm{pH}$ 3.5 during heating at 70,80 and $90^{\circ} \mathrm{C}$.

\begin{tabular}{llll}
\hline Sample & Temperature $\left({ }^{\circ} \mathrm{C}\right)$ & $-k \times 10^{3}\left(\mathrm{~min}^{-1}\right)$ & $t_{1 / 2}(\mathrm{~h})$ \\
\hline Claret red (Ben Van Zanten) & 70 & $1.38^{\mathrm{c}} \pm 0.00$ & $8.40^{\mathrm{a}} \pm 0.00$ \\
& 80 & $3.11^{\mathrm{b}} \pm 0.16$ & $3.75^{\mathrm{b}} \pm 0.21$ \\
& 90 & $5.19^{\mathrm{a}} \pm 0.16$ & $2.25^{\mathrm{c}} \pm 0.07$ \\
Orange-red (Red Ring Hood) & 70 & $1.50^{\mathrm{c}} \pm 0.16$ & $7.79^{\mathrm{a}} \pm 0.83$ \\
& 80 & $3.68^{\mathrm{b}} \pm 0.00$ & $3.12^{\mathrm{b}} \pm 0.03$ \\
& 90 & $6.45^{\mathrm{a}} \pm 0.33$ & $1.81^{\mathrm{c}} \pm 0.12$ \\
Pink (Leo Visser) & 70 & $1.61^{\mathrm{c}} \pm 0.00$ & $7.2^{\mathrm{a}} \pm 0.00$ \\
& 80 & $3.68^{\mathrm{b}} \pm 0.00$ & $3.1^{\mathrm{b}} \pm 0.00$ \\
& 90 & $6.22^{\mathrm{a}} \pm 0.00$ & $1.90^{\mathrm{c}} \pm 0.00$ \\
Violet (Negrita) & 70 & $1.61^{\mathrm{c}} \pm 0.00$ & $7.18^{\mathrm{a}} \pm 0.00$ \\
& 80 & $4.96^{\mathrm{b}} \pm 0.16$ & $2.34^{\mathrm{b}} \pm 0.08$ \\
& 90 & $6.56^{\mathrm{a}} \pm 0.17$ & $1.76^{\mathrm{c}} \pm 0.04$ \\
\hline
\end{tabular}

For each sample and each property; ${ }^{\mathrm{a}-\mathrm{c}}$ : Means in lowercase in the same column compare the temperature and show significant differences at $P<0.05$.
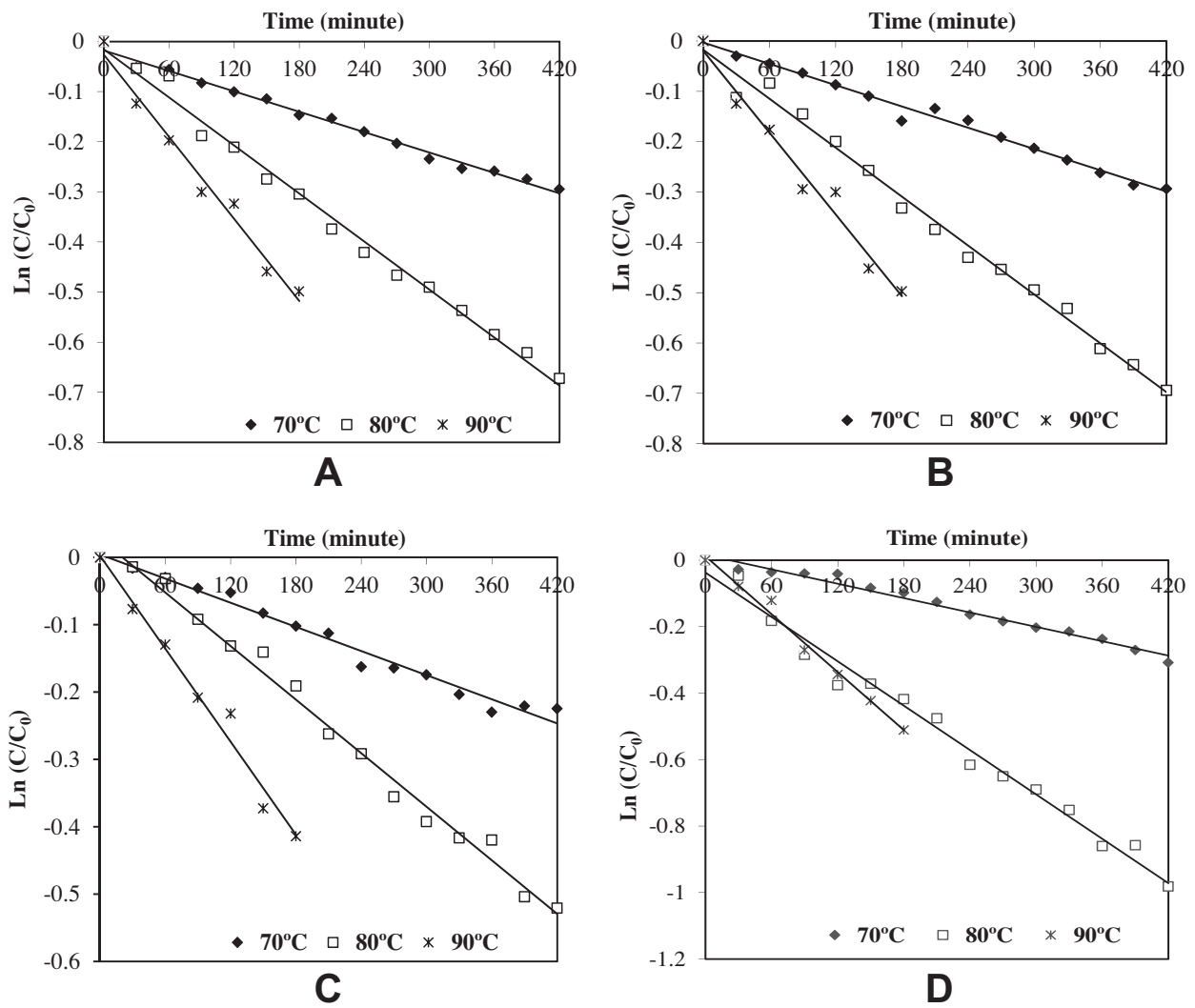

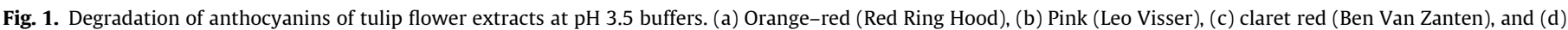
violet (Negrita).

tetrazolium salt converted to purple formazan crystals mainly by mitochondrial succinate dehydrogenase (Wang et al., 1996). In this method, color intensity of the formazan dye is correlated to the number of viable cells. Advantages of MTT test include the sensitivity that even very small number of living cells can be detected and that incidence of errors is minimal since it does not require washing step (Ahmadian et al., 2009). This method is more sensitive than qualitative trypan blue which detects only alive cells (Vandeloosdrecht et al., 1994).

In this study, MTT results showed that red, pink and violet tulip extracts had no cytotoxic activity against MCF-7 cell lines. The present study provides the unique information about the nontoxicity of red, pink and violet tulip flower extracts. Therefore, those extracts can be included in the list of natural colorants like annatto, paprika, curcuma and anthocyanin. On the other hand, yellow and claret red tulip extracts showed somewhat toxicity on the cells. Some plant extracts obtained from Northwestern Brazilian plants, extracts of Carpesium rosulatum and flowers of Butea monosperma, green tea and wheatgrass (Triticum aestivum) have been demonstrated to have anti-cancer properties (Schmidt et al., 2005; Choedon et al., 2010; Aydos et al., 2011; Ferreira et al., 2011; Moon and Zee, 2011). Our result can be valuable since yellow and claret red tulip extracts may have antiproliferative potential against MCF-7 cell line. However, further experiments should be conducted to determine the potential toxic effect of yellow and claret red tulip extracts against cancer cells. 


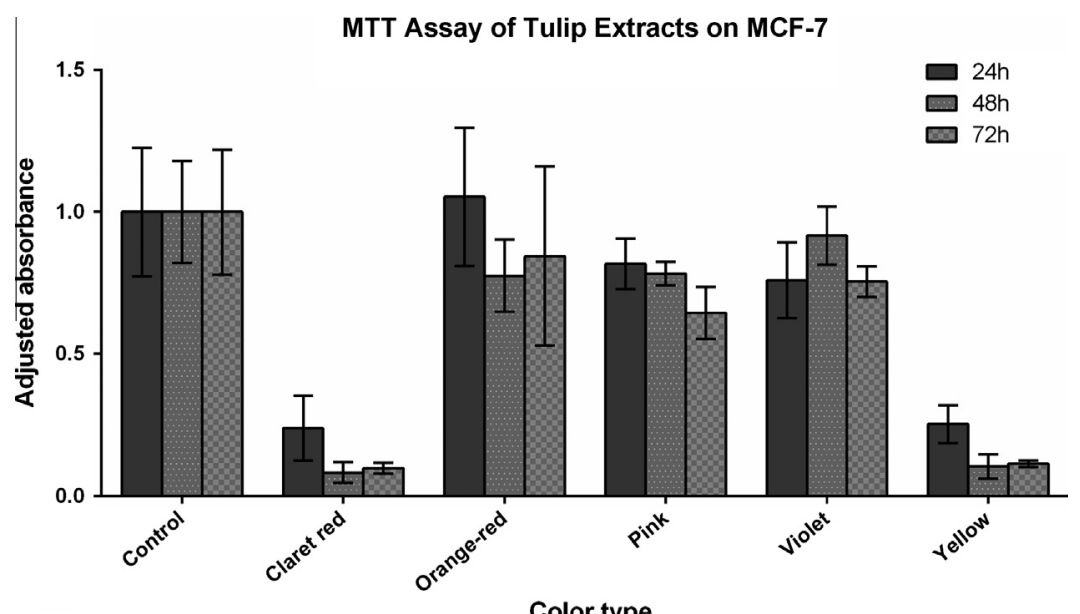

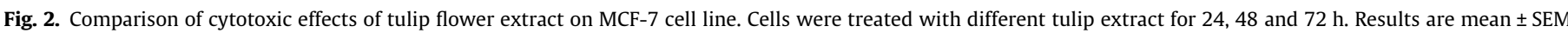
$(n=3)$.

\section{Conclusions}

Tulip flowers obtained from former planting tulip onion at spring are used as ornamental plants. Agronomically, these flowers are cut and wasted to obtain tulip onion at the end of cultivation. The waste tulip flowers were investigated in terms of their bioactive properties. The results of this study demonstrated that the studied tulip flowers had desirable bioactive characteristics. The toxicity results also revealed that color materials obtained from red, pink and violet tulip flowers can be potentially used as coloring agents to be alternative to synthetic agents in food and pharmacology industries. In the further study, bioactivity and physicochemical properties of food products enriched with anthocyanin extracts obtained from the different color tulip flowers can be investigated.

\section{Conflict of Interest}

The authors declare that there are no conflicts of interest.

\section{Acknowledgements}

We would like to thank Istanbul Tree and Landscape Corporation (Istanbul Agac ve Peyzaj A.S.) for providing of tulips. This work was supported by the General Directorate of Agricultural Research (TAGEM/10/AR-GE/03), Ministry of Food, Agriculture and Livestock, Republic of Turkey.

\section{References}

Ahmadian, S., Barar, J., Saei, A.A., Fakhree, M.A.A., Omidi, Y., 2009. Cellular toxicity of nanogenomedicine in MCF-7 cell line: MTT assay. The Journal of Visulalized Experiments 26, 1191.

Aydos, O.S., Avci, A., Ozkan, T., Karadag, A., Gurleyik, E., Altinok, B., Sunguroglu, A. 2011. Antiproliferative, apoptotic and antioxidant activities of wheatgrass (Triticum aestivum L.) extract on CML (K562) cell line. Turkish Journal of Medical Sciences 41, 657-663.

Bechtold, T., Mussak, R., 2009. Handbook of Natural Colorants. Wiley Series in Renewable Resources, United Kingdom.

Brand-Williams, W., Cuvelier, M.E., Berset, C., 1995. Use of a free radical method to evaluate antioxidant activity. LWT - Food Science and Technology 28, 25-30.

Bridle, P., Timberlake, C.F., 1997. Anthocyanins as natural food colours - selected aspects. Food Chemistry 58, 103-109.

Cemeroglu, B., Velioglu, S., Isik, S., 1994. Degradation kinetics of anthocyanins in sour cherry juice and concentrate. Journal of Food Science 59, 1216-1218.

Cevallos-Casals, B.v.A., Cisneros-Zevallos, L., 2004. Stability of anthocyanin-based aqueous extracts of Andean purple corn and red-fleshed sweet potato compared to synthetic and natural colorants. Food Chemistry 86, 69-77.
Choedon, T., Shukla, S.K., Kumar, V., 2010. Chemopreventive and anti-cancer properties of the aqueous extract of flowers of Butea monosperma. Journal of Ethnopharmacology 129, 208-213.

Dyrby, M., Westergaard, N., Stapelfeldt, H., 2001. Light and heat sensitivity of red cabbage extract in soft drink model systems. Food Chemistry 72, 431-437.

Ebrahimabadi, A.H., Djafari-Bidgoli, Z., Mazoochi, A., Kashi, F.J., Batooli, H., 2010 Essential oils composition, antioxidant and antimicrobial activity of the leaves and flowers of Chaerophyllum macropodum Boiss. Food Control 21, 1173-1178.

Feingold, B.F., 1975. Hyperkinesis and learning disabilities linked to artificial food flavors and colors. AJN The American Journal of Nursing 75, 797-803.

Ferreira, P.M.P., Farias, D.F., Viana, M.P., Souza, T.M., Vasconcelos, I.M., Soares, B.M., Pessoa, C., Costa-Lotufo, L.V., Moraes, M.O., Carvalho, A.F.U., 2011. Study of the antiproliferative potential of seed extracts from northeastern Brazilian plants. Anais da Academia Brasileira de Ciências 83, 1045-1058.

Friedman, H., Agami, O., Vinokur, Y., Droby, S., Cohen, L., Refaeli, G., Resnick, N., Umiel, N., 2010. Characterization of yield, sensitivity to Botrytis cinerea and antioxidant content of several rose species suitable for edible flowers. Scientia Horticulturae 123, 395-401.

Fuleki, T., Francis, F.J., 1968. Quantitative methods for anthocyanins. Journal of Food Science 33, 78-83.

Ganesan, L., Margolles-Clark, E., Song, Y., Buchwald, P., 2011. The food colorant erythrosine is a promiscuous protein-protein interaction inhibitor. Biochemical Pharmacology 81, 810-818.

Garzón, G.A., Wrolstad, R.E., 2009. Major anthocyanins and antioxidant activity of nasturtium flowers (Tropaeolum majus). Food Chemistry 114, 44-49.

Giusti, M.M., Wrolstad, R.E., 2001. Unit F1.2.1-13. Anthocyanins. Characterization and Measurement with UV-Visible Spectroscopy. Wiley, New York.

Granholt, A., Thune, P.O., 1975. Urticaria and angioedema induced by antiphlogistics, preservatives and dye additives in food and tablets. Tidsskrift for den Norske Laegeforening 95, 20-22.

Harbourne, N., Jacquier, J.C., Morgan, D.J., Lyng, J.G., 2008. Determination of the degradation kinetics of anthocyanins in a model juice system using isothermal and non-isothermal methods. Food Chemistry 111, 204-208.

Kaisoon, O., Konczak, I., Siriamornpun, S., 2012. Potential health enhancing properties of edible flowers from Thailand. Food Research International 46, 563-571.

Kammerer, D., Carle, R., Schieber, A., 2004. Quantification of anthocyanins in black carrot extracts (Daucus carota ssp. sativus var. atrorubens Alef.) and evaluation of their color properties. European Food Research and Technology 219, 479-486.

Kammerer, D., Schillmöller, S., Maier, O., Schieber, A., Carle, R., 2007. Colour stability of canned strawberries using black carrot and elderberry juice concentrates as natural colourants. European Food Research and Technology 224, 667-679.

Kelley, K.M., Cameron, A.C., Biernbaum, J.A., Poff, K.L., 2003. Effect of storage temperature on the quality of edible flowers. Postharvest Biology and Technology 27, 341-344.

Kirca, A., 2004. Siyah havuc antosiyaninlerinin bazi meyve ürünlerinde isil stabilitesi. Fen Bilimleri Enstitüsü. Ankara Universitesi, Ankara, p. 109.

Kirca, A., Ozkan, M., Cemeroglu, B., 2003. Thermal stability of black carrot anthocyanins in blond orange juice. Journal of Food Quality 26, 361-366.

Kırca, A., Özkan, M., Cemeroğlu, B., 2007. Effects of temperature, solid content and $\mathrm{pH}$ on the stability of black carrot anthocyanins. Food Chemistry 101, 212-218.

Koncic, M.Z., Kremer, D., Gruz, J., Strnad, M., Bisevac, G., Kosalec, I., Samec, D., PiljacZegara, J., Karlovic, K., 2010. Antioxidant and antimicrobial properties of Moltkia petraea (Tratt.) Griseb. flower, leaf and stem infusions. Food and Chemical Toxicology 48, 1537-1542.

Ksouri, R., Falleh, H., Megdiche, W., Trabelsi, N., Mhamdi, B., Chaieb, K., Bakrouf, A. Magné, C., Abdelly, C., 2009. Antioxidant and antimicrobial activities of the edible medicinal halophyte Tamarix gallica $\mathrm{L}$. and related polyphenolic constituents. Food and Chemical Toxicology 47, 2083-2091. 
Laloo, D., Sah, A.N., 2011. Antioxidant activities of three Indian commercially available Nagakesar: an in vitro study. Journal of Chemical and Pharmaceutical Research 3, 277-283.

Liu, B.H., Wu, T.S., Su, M.C., Chung, C.P., Yu, F.Y., 2005. Evaluation of citrinin occurrence and cytotoxicity in Monascus fermentation products. Journal of Agriculture and Food Chemistry 53, 170-175.

Michaelsson, G., Juhlin, L., 1973. Urticaria induced by preservatives and dye additives in food and drugs. British Journal of Dermatology 88, 525-532.

Mlcek, J., Rop, O., 2011. Fresh edible flowers of ornamental plants - a new source of nutraceutical foods. Trends in Food Science \& Technology 22, 561-569.

Moon, H.I., Zee, O., 2011. Sesquiterpene lactones from Carpesium rosulatum with potential cytotoxicity against five human cancer cell lines. Human \& Experimental Toxicology 30, 1083-1087.

Nagavani, V., Rao, T.R., 2010. Evaluation of antioxidant potential and identification of polyphenols by RP-HPLC in Michelia champaca flowers. Advances in Biological Research 4, 159-168.

Pliszka, B., Huszcza-Ciolkowska, G., Mieleszko, E., Czaplicki, S., 2009. Stability and antioxidative properties of acylated anthocyanins in three cultivars of red cabbage (Brassica oleracea L. var. capitata L. f. rubra). Journal of the Science of Food and Agriculture 89, 1154-1158.

Prieto, P., Pineda, M., Aguilar, M., 1999. Spectrophotometric quantitation of antioxidant capacity through the formation of a phosphomolybdenum complex: Specific application to the determination of vitamin E. Analytical Biochemistry 269, 337-341.

Reyes, L.F., Cisneros-Zevallos, L., 2007. Degradation kinetics and colour of anthocyanins in aqueous extracts of purple- and red-flesh potatoes (Solanum tuberosum L.). Food Chemistry 100, 885-894.

Sagdic, O., Karahan, A.G., Ozcan, M., Ozkan, G., 2003. Note: effect of some spice extracts on bacterial inhibition. Food Science and Technology International 9, 353-358.
Samec, D., Gruz, J., Strnad, M., Kremer, D., Kosalec, I., Grubesic, R.J., Karlovic, K., Lucic, A., Piljac-Zegarac, J., 2010. Antioxidant and antimicrobial properties of Teucrium arduini L. (Lamiaceae) flower and leaf infusions (Teucrium arduini L.) antioxidant capacity. Food and Chemical Toxicology 48, 113-119.

Schmidt, M. Schmitz, H., Baumgart, A, Guedon, D., Netsch, M.I, Kreuter, M.H., Schmidlin, C.B., Schrenk, D., 2005. Toxicity of green tea extracts and their constituents in rat hepatocytes in primary culture. Food and Chemical Toxicology 43, 307-314.

Silbergeld, E.K., Anderson, S.M., 1982. Artificial food colors and childhood behavior disorders. Bulletin of the New York Academy of Medicine 58, 275-295.

Singleton, V.L., Rossi, J.A.J., 1965. Colorimetry of total phenolics with phosphomolybdicphosphotungstic acid reagents. American Journal of Enology and Viticulture 16, 144

Tai, Z., Cai, L., Dai, L., Dong, L., Wang, M., Yang, Y., Cao, Q., Ding, Z., 2011. Antioxidant activity and chemical constituents of edible flower of Sophora viciifolia. Food Chemistry 126, 1648-1654.

Vandeloosdrecht, A.A., Beelen, R.H.J., Ossenkoppele, G.J., Broekhoven, M.G., Langenhuijsen, M., 1994. A tetrazolium-based colorimetric MTT assay to quantitate human monocyte mediated cytotoxicity against leukemic-cells from cell-lines and patients with acute myeloid-leukemia. Journal of Immunological Methods 174, 311-320.

Vidotti, E.C., Costa, W.F., Oliveira, C.C., 2006. Development of a green chromatographic method for determination of colorants in food samples. Talanta 68, 516-521.

Wang, H.Z., Chang, C.H., Lin, C.P., Tsai, M.C., 1996. Using MTT viability assay to test the cytotoxicity of antibiotics and steroid to cultured porcine corneal endothelial cells. Journal of Ocular Pharmacology and Therapeutics 12, 35-43.

Wang, W.D., Xu, S.Y., 2007. Degradation kinetics of anthocyanins in blackberry juice and concentrate. Journal of Food Engineering 82, 271-275.

Wrolstad, R.E., 1976. Color and pigment analyses in fruit products. Station Bulletin 624, Agric. Exp. Stn.. Oregon State University, Corvallis. 